\title{
KARAKTERISTIK PERTUMBUHAN MELADA DAN LADA SAMBUNG
}

\author{
Growth Characteristics of Piper colubrinum and Grafting of \\ Piper nigrum/Piper colubrinum \\ Nova Anggraini ${ }^{1}$, Rusdi Evizal ${ }^{2 *}$, Liska Mutiara Septiana ${ }^{3}$ \\ ${ }^{1}$ Badan Penelitian dan Pengembangan Daerah Provinsi Lampung \\ Jl. Kantor Pos No 2 Telukbetung, Bandar Lampung \\ ${ }^{2}$ Jurusan Agroteknologi, Fakultas Pertanian, Universitas Lampung \\ ${ }^{3}$ Jurusan Ilmu Tanah, Fakultas Pertanian, Universitas Lampung \\ Jl. Sumantri Brojonegoro No 1 Gedung Meneng, Bandar Lampung 35145 \\ *E-mail korespondensi: rusdi.evizal@fp.unila.ac.id
}

\begin{abstract}
ABSTRAK
Tanaman melada digunakan sebagai batang bawah lada sambung karena tahan terhadap jamur penyebab penyakit busuk pangkal batang lada. Pembibitan lada sambung dan perkebunan lada sambung mulai dikembangkan oleh petani di Lampung. Penelitian ini bertujuan untuk mempelajari karakteristik pertumbuhan tanaman melada dan lada sambung. Penelitian ini dilakukan di kebun melada dan lada sambung milik petani di Desa Air Kubang, Kecamatan Air Naningan, menggunakan metode survei. Sampel tanaman ditentukan secara acak pada kebun induk melada dan kebun lada sambung. Hasil menunjukkan bahwa: (1) Tanaman melada mulai umur 1 tahun membentuk cabang plagiotrop yang berdiameter kecil setiap 1-2 buku cabang ortotrop, tetapi lambat membentuk percabangan ortotrop, (2) Setelah pemangkasan kedua (panen stek kedua) sebanyak 22\% tanaman bercabang ortotrop 2-3 cabang. Hasil stek melada panen kesatu sampai ketiga semakin meningkat sebesar 21-25\% dibandingkan hasil sebelumnya. Pada panen ketiga, produksi stek mencapai 5066 stek per luas lahan $400 \mathrm{~m}^{2}$ atau setara 126.650 stek 2 buku per ha lahan yang dipanen setiap 2 bulan, (3) Pada umur 18 bulan, dibandingkan lada non-sambung, lada sambung menunjukkan indeks kehijauan daun yang lebih besar, diameter batang yang lebih besar, diameter cabang plagiotrop yang lebih besar, jumlah cabang ortotrop dan cabang plagiotrop yang lebih banyak, dan 15,6\% tanaman sudah berbunga candik.
\end{abstract}

Kata kunci: , Candik bunga, lada sambung, pertumbuhan, Piper colubrinum, stek

\begin{abstract}
Wild pepper of Piper colubrinum Link is used as rootstocks for grafted black pepper (Piper nigrum/Piper colubrinum) because its resistance to fungi that cause root rot disease. Grafted black pepper nurseries and plantations began to be developed by farmers in Lampung. This research aims to study the growth characteristics of wild pepper and grafted black pepper plants. The research was conducted in the field of wild pepper and grafted black pepper owned by farmers in Air Kubang Village, Air Naningan District, Tanggamus, Lampung, using survey method. Plant samples were determined randomly in the fields. The results showed that: (1) Wild pepper plants starts at the age of 1 year form plagiotropic branches with small diameters every 1-2 orthotropic branches, but slowly form orthotropic branches; (2) After the second pruning (of harvesting cuttings) $22 \%$ of the plants form orthotropic branches. The yield of pepper cuttings from the first to third harvests increased by 21-25\% compared to the previous yield. In the third harvest, the production of cuttings reached 5066 cuttings (2 nodes) per $400 \mathrm{~m}^{2}$ land area or equivalent to 126,650 cuttings per ha of land harvested every 2 months; (3) At the age of 18 months, compared to non-grafted, grafted black pepper showed a greater greeness leaf index, larger stem diameter, larger plagiotropic branch diameter, higher number of orthotropic and plagiotropic branches, and $15.6 \%$ of grafted black pepper plants were flowering.
\end{abstract}

Key words : Black pepper, cutting, flowering, growth, grafting, Piper colubrinum 


\section{PENDAHULUAN}

Melada (Piper colubrinum Link.) merupakan anggota famili Piperaceae berhabitus perdu, tidak merambat, batang berbuku kokoh dan melebar, tumbuh banyak akar udara pada dekat permukaan tanah, tandan bunga tumbuh tegak dan berbentuk silendris, berbunga sepanjang tahun, membentuk buah yang kecil mencapai 300 buah per tandan (Vanaja et al. 2008; Chaveerach et al. 2008). Karena bersifat resisten terhadap serangan jamur Phytophthora capsici penyebab penyakit busuk pangkal batang lada dan resisten terhadap nematoda (Meloidogyne incognita), tanaman melada dimanfaatkan sebagai batang bawah pada grafting lada sambung (Alconero et al. 1972; Chinnapappa et al. 2018), sebagai tetua hibrida lada x melada (Vanaja et al. 2008; Jagtap et al. 2016), dan sebagai donor gen resisten Phytophthora capsici pada rekayasa lada transgenik (Sinoj et al. 2014).

Sebagai anggota famili Piperaceae yang umumnya merupakan tanaman fitofarmaka (Evizal 2013), tanaman melada berpotensi sebagai tanaman fitofarmaka sebagai antioksidan dan sitotoksik pada kanker servik (Sruthi and Zachariah 2017). Di antara famili Piperaceae, melada memiliki kandungan fenolik yang paling tinggi antara lain terdiri dari asam salicylic, 2-pyrocatechuic, gentisic, 4-coumaric, caffeic, dan ferulic (Sruthi and Zachariah 2016).

Tanaman melada tumbuh pada habitat rawa. Pada keadaan air yang tergenang tetap tumbuh dengan baik jika kedudukan tanaman di atas muka air. Tanaman ini diperbanyak dengan stek batang, mudah berakar, tumbuh cepat, dan perakaran yang kuat (Raja et al. 2018).

Kendala utama dalam budidaya lada adalah serangan penyakit busuk pangkal batang lada yang dapat menyebabkan kematian tanaman lada sehingga perlu dilakukan penyulaman secara rutin setiap tahun. Kematian tanaman lada semakin bertambah ketika musim kemarau panjang (Prasmatiwi and Evizal 2020). Untuk itu perlu diseleksi dan dikembangkan varietas lada yang toleran variabilitas iklim (Vijayakumari and Puthur 2014). Pengembangan lada sambung untuk mengatasi masalah penyakit busuk pangkal batang lada mungkin menghadapi kendala karena tanaman melada lebih rentan terhadap kekeringan daripada tanaman lada (Krishnamurthy and Saji 2006). Karakeristik pertumbuhan tanaman melada perlu dilakukan tidak hanya untuk penyediaan bahan tanam tetapi juga untuk mendukung keberhasilan penanaman dan pengembangan lada sambung.

Melada telah dimanfaatkan sebagai batang bawah untuk disambung dengan lada biasa sehingga tanaman lada sambung menjadi resisten terhadap penyakit busuk pangkal batang lada (Alconero et al. 1972). Keberhasilan teknis penyambungan telah banyak dilaporkan misalnya Nguyen et al. (2020) melaporkan sampai umur 3 bulan $82 \%$ tanaman lada sambung berhasil tumbuh dan bertunas. Namun keberhasilan pertumbuhan lada sambung di pembibitan dilaporkan belum tentu bersifat permanen ketika ditanam di lapangan (Garner and Beakbane, 1968).

Ketika sampai tanaman mencapai usia produktif semakin tampak adanya inkompatibilitas pada sambungan (Alconero et al. 1972) yang disebabkan perbedaan sistem pembuluh angkut antar spesies Piper (Yang and Chen 2017). Pada batang ortotrop melada terdapat 11-14 berkas angkut modular dan 42-46 berkas angkut periferal, sedangkan pada lada hanya terdapat 9 berkas angkut modular dan 34-38 berkas angkut periferal (Ravindran and Remashree 1998). Ketika berhasil berbuah, produktivitas lada sambung dilaporkan lebih rendah dan lebih rentan terhadap kekeringan daripada lada non-sambung (An et al. 2019). Oleh karena itu perlu diteliti sifat pertumbuhan lada sambung dalam upaya inovasi perbaikan agroteknologi budidaya lada sambung sebagimana disarankan oleh (Evizal and 
Prasmatiwi 2019). Penelitian ini bertujuan untuk mempelajari karakteristik pertumbuhan tanaman melada dan lada sambung.

\section{METODE PENELITIAN}

Penelitian dilakukan di kebun melada dan lada sambung milik petani di Desa Air Kubang, Kecamatan Air Naningan, Tanggamus, pada bulan Januari 2020 sampai Juni 2021. Penelitian dilakukan menggunakan metode survei. Karakterisitik pertumbuhan melada di amati pada pembibitan melada seluas $400 \mathrm{~m}^{2}$, pertanaman seluas $800 \mathrm{~m}^{2}$ dengan jarak tanam $50 \times 50 \mathrm{~cm}$, yang ditanam tanpa pohon naungan. Pertanaman ini bertujuan untuk memproduksi bahan stek melada. Tanaman dipelihara dengan cara penyiangan tiap 3 bulan dan pemupukan setelah panen stek dengan dosis pupuk Urea $10 \mathrm{~g} /$ tanaman.

Karakterisitik pertumbuhan lada sambung diamati pada perkebunan lada sambung seluas 0,5 ha dengan jarak tanam $2,5 \times 2,5 \mathrm{~m}$, yang ditanam pada pohon panjatan kapuk. Pemeliharaan meliputi pengendalian gulma menggunakan mesin babat dan dibokor setiap 3 bulan. Pada tahun pertama dilakukan aplikasi pupuk kandang sebanyak 5 liter per tanaman. Setelah berumur 1 tahun dilakukan pemupukan NPK (15:15:15) dengan dosis 200g/tanaman/tahun. Pemupukan dilakukan 2 kali setahun, yaitu pada bulan Maret dan Oktober.

Sampel bibit dan tanaman ditentukan secara acak pada 4 blok lahan, masingmasing diamati 4 pohon. Karakter yang diamati antara lain karakter daun, cabang ortotrop, cabang plagiotrop, dan bunga. Data disajikan secara kuantitatif dan kualitatif. Pengamatan luas daun dilakukan dengan menggunakan aplikasi Petiole pada Android. Indeks kehijauan daun (Greeness Leaf Index = GLI) diperoleh dari nilai RGB pada daun yang diamati menggunakan aplikasi Colormeter pada Android dengan rumus (Xue and $\mathrm{Su} 2017)$ : $\mathrm{GLI}=((2,0 \mathrm{x}$

$$
\text { Green })-(\text { Red }+ \text { Blue })) /((2,0 \times \text { Green })+
$$
Red + Blue)).

\section{HASIL DAN PEMBAHASAN}

Hasil pengamatan pertumbuhan tanaman melada di polibag umur 3 bulan, di lahan umur 6 bulan dan di lahan umur 2 tahun disajikan pada Tabel 1. Setelah ditanam di lahan, maka tanaman melada akan tumbuh dengan daun yang lebih besar akan tetapi warna daun lebih hijau muda. Ketika di bawah naungan pembibitan maka indeks kehijaun daun akan sedikit lebih tinggi. Indeks kehijauan daun terkait dengan kandungan klorofil (Yadav et al 2010).

Tanaman melada memiliki akar udara, yang mudah terlihat setelah tanaman ditanam di lahan. Dari buku akan muncul akar udara yang baru dan aktif tumbuh ditandai dengan warna akar yang putih di bagian ujung berjumlah 4-8 buah per tanaman. Batang melada yang sering dipangkas akan tumbuh banyak tunas cabang yang mencapai 8,8 tunas. Dengan demikian diperoleh hasil bahan stek yang lebih banyak.

Ketika ditanam di lahan, ruas tumbuh lebih panjang, membentuk ranting buah setiap 1-2 buku ortotrop akan bercabang plagiotrop. Hasil perhitungan rasio cabang plagiotrop (jumlah plagiotrop/jumah buku) adalah 0,46 untuk melada umur 2 tahun. Akan tetapi pada tanaman yang setahun tidak dipangkas sehingga tumbuh meninggi maka pada setiap buku cabang ortotrop muncul cabang (ranting) plagiotrop, yang berarti rasio cabang plagiotrop bernilai 1 .

Petani umumnya hanya memilih cabang ortotrop sebagai bahan stek karena berdiameter lebih besar sehingga cepat tumbuh. Akan tetapi cabang plagiotrop juga dapat digunakan sebagai bahan stek yang juga menghasilkan tanaman perdu dan tumbuh tegak. Hal ini berbeda dengan tanaman lada yang jika ditanam cabang plagiotrop akan menumbuhkan tanaman perdu yang tidak merambat. Ini tampaknya terkait dengan sifat pertumbuhan melada 
yang memang tumbuh tegak. Baik cabang ortotrop maupun plagiotrop menghasilkan pertumbuhan batang yang tegak.

Tabel 1. Karakterisitik pertumbuhan melada

\begin{tabular}{llll}
\hline Variabel pengamatan & $\begin{array}{l}\text { Di polybag 3 } \\
\text { bulan }\end{array}$ & $\begin{array}{l}\text { Di lahan umur 6 } \\
\text { bulan }\end{array}$ & $\begin{array}{l}\text { Di lahan umur 2 } \\
\text { tahun }\end{array}$ \\
\hline Luas daun $\left(\mathrm{cm}^{2}\right)$ & $111,73 \pm 13,70$ & $112.69 \pm 14,58$ & $138,39 \pm 16,84$ \\
Indeks kehijauan daun & $0,29 \pm 0,07$ & $0,26 \pm 0,06$ & $0,24 \pm 0,03$ \\
Jumlah akar udara hidup & 0 & $4,2 \pm 0,84$ & $7,8 \pm 2,17$ \\
Diameter batang $(\mathrm{cm})$ & $0,68 \pm 0,04$ & $0,91 \pm 0,07$ & $2,22 \pm 0,41$ \\
Diameter tunas $(\mathrm{cm})$ & $0,68 \pm 0,04$ & $0,78 \pm 0,05$ & $0,83 \pm 0,04$ \\
Jumlah tunas & $1,1 \pm 0,44$ & $1,2 \pm 0,45$ & $8,8 \pm 1,48$ \\
Panjang tunas $(\mathrm{cm})$ & $55,22 \pm 1,88$ & $85,4 \pm 5,42$ & $64,38 \pm 14,29$ \\
Jumlah buku per tunas & $5,4 \pm 0,54$ & $6,4 \pm 0,55$ & $5,2 \pm 0,84$ \\
Panjang ruas tunas $(\mathrm{cm})$ & $10,29 \pm 0,95$ & $13,38 \pm 0,99$ & $12,52 \pm 2,88$ \\
Jumlah ranting plagiotrop/tunas & 0 & $4,2 \pm 0,84$ & $2,4 \pm 0,55$ \\
Panjang ruas ranting $(\mathrm{cm})$ & 0 & $5,96 \pm 1,22$ & $7,76 \pm 0,44$ \\
\hline
\end{tabular}

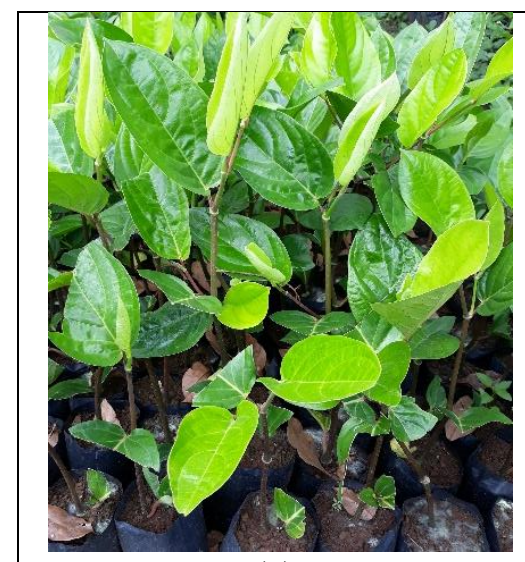

(a)

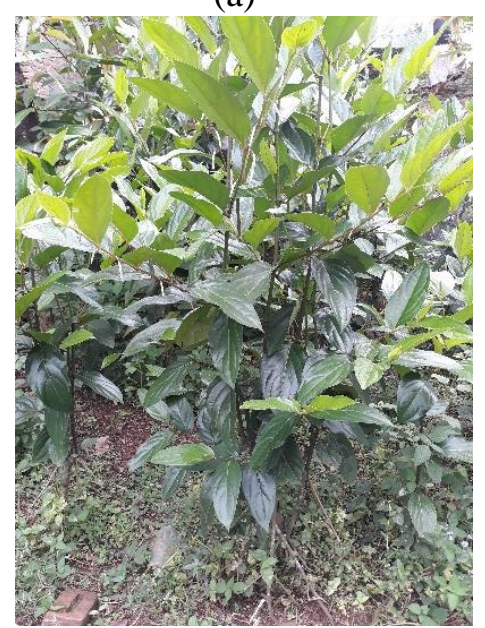

(b)

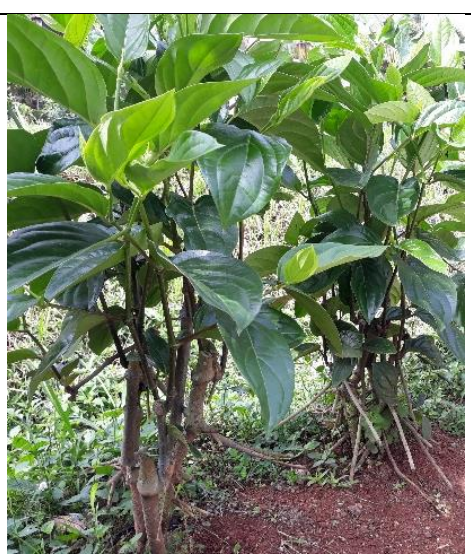

(c)

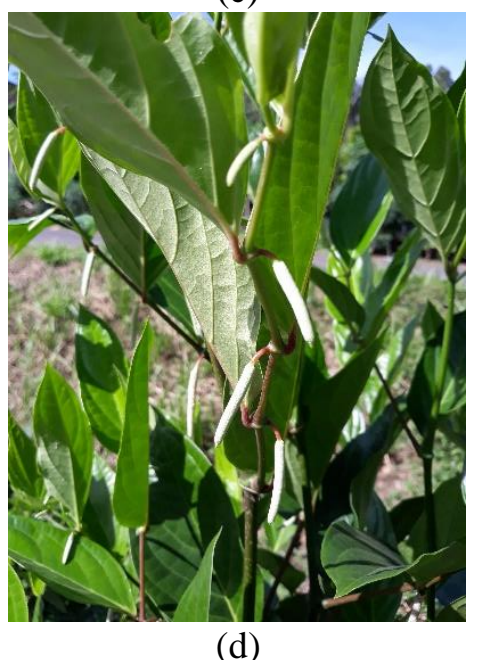

Gambar 1. Performa pohon melada, (a) di bibitan, (b) umur 1 tahun, (c) umur 2 tahun, (d) pohon berdaun tegak dan berbunga 
Selain berdiamater kecil, ranting plagiotrop berukuran panjang ruas $6-8 \mathrm{~cm}$, lebih pendek daripada cabang ortotrop yang berkisar panjang 10-13 cm. Jika disemai sebagai stek, maka cabang ini akan berangsur menghasilkan tunas bercabang lebih besar sampai kemudian bertunas berukuran normal cabang ortotrop.

Secara visual tanaman melada disajikan pada Gambar 1. Tanaman ini tumbuh tidak merambat, memiliki daun yang lebih lebar dan panjang daripada tanaman lada, wana daun yang lebih hijau muda, lebih tipis sehingga lebih mudah layu apabila kekurangan air, daun tegak mengarah ke atas. Daun-daun tua yang relatif ternaungi akan berwarna lebih hijau. Batang berbintik putih, berwarna hijau, agak merah ketika terkena matahari penuh. Pertumbuhan yang kuat ditunjukkan oleh daun lebih besar, ruas lebih panjang, dan lebih lunak.

Ketika berumur 1 tahun tanaman ini mulai berbunga, berwarna putih, bertangkai agak merah, tumbuh mengarah ke samping atau ke bawah. Tanaman selalu berbunga, tanpa musim. Setelah muncul 3-4 bunga per ranting plagiotrop, maka bunga akan menjadi kecoklatan dan gugur.

Pada Gambar 1c tampak bahwa akar udara tumbuh dari buku dekat permukaan tanah. Beberapa akar udara berhasil sampai ke tanah dan berfungsi sebagai akar biasa yang mendukung pertumbuhan tanaman. Sebagian akar mengering dan mati sebelum mencapai tanah. Adanya akar udara biasanya menunjukkan kemampuan beradaptasi pada keadaan lahan tergenang.

Ketiak daun memiliki mata tunas yang dapat berkembang menjadi cabang ortotrop maupun plagiotrop, namun umumnya yang tumbuh adalah cabang plagiotrop. Cabang atau ranting plagiotrop dapat tumbuh dari setiap ketiak daun kearah samping, sesuai arah duduk daun, yaitu bergantian ke kiri, ke depan, ke kanan, dan ke belakang.

\section{Produksi Stek Melada}

Melada sebagai sumber bahan tanam ditanam menggunakan bibit asal stek 2 buku yang disemai di polibag yang berumur 3 bulan. Pada umur 3 bulan setelah tanam, melada sudah dapat dipanen stek untuk digunakan sebagai bahan stek 2 buku. Pembibitan melada merupakan salah satu sumber bahan tanam, akan tetapi jumlah stek yang dapat dipanen hanya sedikit. Jika ingin memperoleh bahan stek yang lebih banyak maka bibit melada ditanam di lahan kebun dengan jarak tanam 0,5 $\mathrm{m}$ x 0,5 $\mathrm{m}$.

Produksi stek pada panen pertama masih relatif sedikit tampaknya karena pertumbuhan tunas masih lambat mungkin karena perakaran yang belum banyak. Pada panen kedua dihasilkan stek yang lebih banyak. Demikian juga panen ketiga hasil stek lebih meningkat, dengan peningkat masing-masing $25 \%$ dan $21 \%$. Pada panen ketiga, produksi stek mencapai 5066 stek per luas lahan $400 \mathrm{~m}^{2}$ atau setara 126.650 stek 2 buku per ha lahan. Untuk para penangkar bibit lada sambung, maka kebun induk bahan stek batang bawah $P$. colubrinum seluas $400 \mathrm{~m}^{2}$ sudah cukup untuk memenuhi kebutuhan batang bawah.

Hasil penelitian ini menunjukkan bahwa tanaman melada lambat membentuk percabangan ortotrop. Pada panen pertama tanaman berlum bercabang. Pada panen kedua panen beberapa tanaman bercabang dua. Pada panen ketiga terdapat $22 \%$ tanaman yang bercabang 2 atau 3. Hal ini berbeda dengan sifat pertumbuhan lada. Pemangkasan cabang ortotrop akan segera mendorong tanaman lada bercabang. Panen stek lada pada pohon muda juga dimaksudkan sebagai pemangkasan bentuk yaitu untuk mendorong pembentukan cabang ortotrop sejak $30 \mathrm{~cm}$ dari permukaan tanah. Demikian selanjutnya lada dipangkas pada ketinggian dimana buku diharapkan akan bercabang. 
Tabel 2. Produksi stek melada setiap 2 bulan

\begin{tabular}{llll}
\hline Variabel panen stek & Panen ke-1 & Panen ke-2 & Panen ke-3 \\
\hline Panjang tunas $(\mathrm{cm})$ & $47,80 \pm 8,99$ & $67,37 \pm 10,61$ & $79,78 \pm 17,54$ \\
Jumlah tunas/batang & $1,00 \pm 0,00$ & $1,11 \pm 0,32$ & $1,27 \pm 0,57$ \\
Jumlah buku/tunas & $4,30 \pm 0,95$ & $5,50 \pm 1,19$ & $5,78 \pm 1,11$ \\
Produksi stek 2 buku/400 $\mathrm{m}^{2} / 2$ bulan & $3360 \pm 506$ & $4200 \pm 828$ & $5066 \pm 2212$ \\
\hline
\end{tabular}

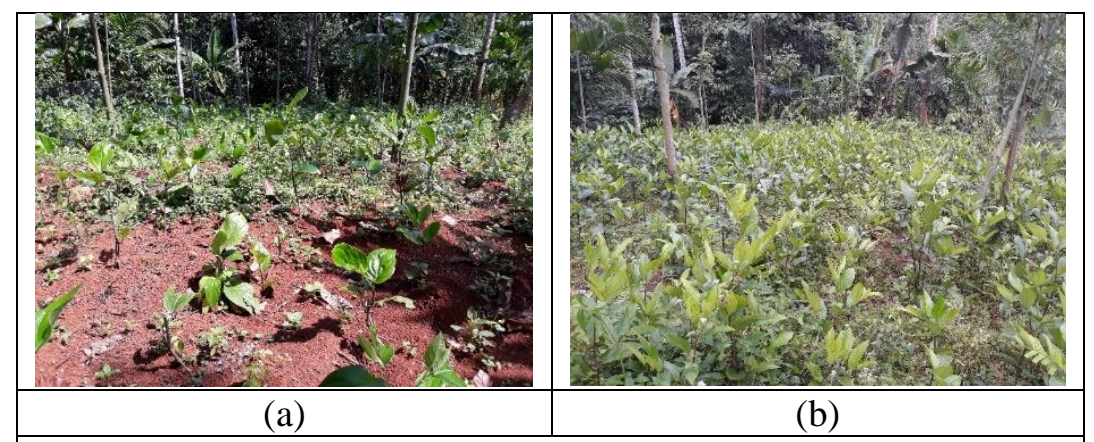

Gambar 2. Kebun induk stek melada, (a) setelah panen kesatu dan (b) sebelum panen ketiga

Gambar 2 menyajikan pertanaman melada sumber bahan stek dari panen awal sampai berumur 7 sebelum dipanen ketiga. Tanaman umumnya memiliki cabang ortotrop yang belum membentuk cabang. Setelah satu cabang ortotrop dipanen, hanya menumbuhkan satu cabang ortotrop. Ketika umur 1 tahun tanaman akan memiliki 2-3 cabang ortotrop (Gambar 1).

\section{Pertumbuhan Lada Sambung}

Stek melada 2 buku setelah disemai 23 bulan disambung dengan lada biasa yang dijual petani sebagai bibit lada sambung. Varietas lada yang umum digunakan adalah Natar 1 yang merupakan varietas unggul asal Lampung. Setelah bibit lada sambung berumur 3 bulan atau berdaun 6-7 helai, maka bibit siap ditanam di kebun. Hasil observasi ketika survei menunjukkan tingginya kematian tanaman lada sambung ketika transplanting akibat stress transplanting dan keadaan sambungan yang belum kuat. Untuk itu perlu dilakukan penyulaman.

Untuk mengatasi angka kematian transplanting yang tinggi, petani menanam bibit melada di dekat pohon tajar. Setelah tumbuh maka tanaman melada disambung dengan tanaman lada (Hidayat et al. 2021). Cara ini menghasilkan tanaman lada sambung dengan sambungan terletak di atas permukaan tanah. Jika ditanam bibit lada sambung maka sambungan akan tertimbun tanah ketika kegiatan membokor dan memupuk. Dikhawatirkan batang lada di dalam tanah akan rentan terhadap serangan jamur penyebab penyakit busuk pangkal batang. Tanaman lada hasil sambung melada di kebun akan tumbuh lebih cepat karena didukung pertumbuhan batang bawah yang sudah kuat namun perlu penelitian lebih lanjut.

Penelitian mengamati pertumbuhan lada yang ditanam menggunakan bibit lada sambung dan dibandingkan dengan pertumbuhan lada menggunakan bibit nonsambung yaitu dari cabang tanah 7 ruas. Tabel 3 menunjukkan pertumbuhan lada sambung sejak umur 6 bulan sampai 16 bulan yang tidak berbeda nyata dengan pertumbuhan lada non-sambung pada peubah tinggi tanaman dan jumlah cabang panjat, namun berbeda nyata pada peubah jumlah cabang buah. 
Tabel 3. Pertumbuhan lada sambung dibanding non-sambung

\begin{tabular}{lllll}
\hline Peubah & Jenis lada & Umur 6 bln & Umur 11 bln & Umur 16 bln \\
\hline Tinggi tanaman & Lada Sambung & $57,4 \pm 19,7$ & $114,7 \pm 18,2$ & $194,7 \pm 30,3$ \\
& Lada non-sambung & $39,5 \pm 18,7$ & $105,3 \pm 10,3$ & $140,2 \pm 26,6$ \\
Jml cabang panjat & Lada Sambung & $2,1 \pm 0,4$ & $3,2 \pm 1,7$ & $4,7 \pm 1,8$ \\
& Lada non-sambung & $1,2 \pm 0,3$ & $1,8 \pm 0,5$ & $2,6 \pm 1,4$ \\
Jml cabang Buah & Lada Sambung & $4,8 \pm 1,9$ & $16,7 \pm 6,2$ & $20,4 \pm 9,1$ \\
& Lada non-sambung & $0,0 \pm 0,0$ & $2,6 \pm 1,7$ & $4,4 \pm 1,9$
\end{tabular}

Tabel 4. Pertumbuhan lada sambung umur 18 bulan

\begin{tabular}{lll}
\hline Peubah & Lada sambung & Lada non-sambung \\
\hline Luas daun (cm2) & $96,22 \pm 7,52$ & $85,35 \pm 14,47$ \\
Indeks kehijauan daun & $0,35 \pm 0,15$ & $0,17 \pm 0,06$ \\
Jml buku/cab panjat & $26,38 \pm 3,15$ & $24,08 \pm 2,85$ \\
Diameter batang bawah $(\mathrm{mm})$ & $15,26 \pm 2,63$ & - \\
Diameter batang atas $(\mathrm{mm})$ & $11,57 \pm 3,01$ & $5,49 \pm 1,09$ \\
Rasio diameter atas/bawah & $0,72 \pm 0,12$ & $1,00 \pm 0,00$ \\
Diameter cabang plagiotrop (mm) & $6,75 \pm 0,70$ & $5,49 \pm 0,40$ \\
Jumlah cabang ortotrop & $4,48 \pm 1,07$ & $2,22 \pm 0,15$ \\
Jumlah cabang plagiotrop & $20,82 \pm 5,71$ & $8,37 \pm 1,76$ \\
Indeks percabangan ortotrop & $0,17 \pm 0,04$ & $0,09 \pm 0,009$ \\
Indeks percabangan plagiotrop & $0,77 \pm 0,19$ & $0,35 \pm 0,05$ \\
Jumlah pohon berbunga $(\%)$ & 15,62 & 0,00 \\
Jumlah bunga candik & 19,30 & 0,00 \\
\hline
\end{tabular}

Indeks cab ortotrop $=\mathrm{jml} \mathrm{cab} \mathrm{ortotrop/jml} \mathrm{buku} \mathrm{cabang} \mathrm{ortotrop}$

Indeks cab plagiotrop $=\mathrm{jml}$ cab plagiotrop/jml buku cabang ortotrop

Tanaman lada yang ditanam dari cabang tanah memang dikenal lambat membentuk cabang plagiotrop. Petani banyak yang menggunakan bahan tanam ini karena banyak tersedia di kebun lada (Prasmatiwi and Evizal 2020) bahkan tanpa harus membeli. Untuk mendorong percabangan plagiotrop maka dilakukan pemangkasan sekaligus memanen bahan stek.

Tabel 4 menyajikan karakteristik pertumbuhan lada sambung ketika tanaman lada sambung berumur 18 bulan dan mulai berbunga. Dibandingkan lada non-sambung, lada sambung menunjukkan indeks kehijauan daun yang lebih besar, diameter batang yang lebih besar, diameter cabang plagiotrop yang lebih besar, jumlah cabang ortotrop yang lebih banyak, dan jumlah cabang plagiotrop yang lebih banyak. Indeks percabangan ortotrop lada sambung lebih tinggi daripada lada non-sambung, yaitu terdapat 1,7 cabang ortotrop pada 10 buku cabang ortotrop, sedangkan pada lada nonsambung hanya terdapat 0,9 cabang ortotrop per 10 cabang ortotrop.

Indeks percabangan plagiotrop lada sambung lebih tinggi daripada lada nonsambung, yaitu terdapat 7,7 cabang plagiotrop pada 10 buku cabang ortotrop, sedangkan pada lada non-sambung hanya terdapat 3,5 cabang plagiotrop per 10 cabang ortotrop. Indeks ini menunjukkan pada lada sambung, cabang ortotrop akan membentuk cabang plagiotrop hampir pada setiap buku (indeks plagiotrop $=0,77$ ), sedangkan pada lada non-sambung setiap 3 buku cabang ortotrop akan membentuk 1 cabang plagiotrop (indeks plagiotrop $=0,35$ ).

Pada lada sambung dilakukan pengukuran diameter batang bawah dan batang atas. Hal ini bertujuan untuk 
mengetahui keadaan sambungan apakah pertumbuhan batang lada (batang atas) dapat sama dengan pertumbuhan batang melada (batang bawah). Hasil menunjukkan bahwa diameter batang bawah tumbuh lebih cepat daripada diameter batang atas dengan rasio 0,72. Dengan demikian sambungan tidak mulus tertutup kalus. Apakah hal ini dapat menyebabkan keretakan pada sambungan, perlu dilakukan penelitian lebih lanjut.
Pada umur 18 bulan, sebanyak 15,6\% tanaman lada sambung sudah mulai berbunga dengan rata-rata jumlah tandan bunga atau 19,3. Pengamatan harus dilakukan lebih lanjut untuk mengukur produktivitas tanaman lada sambung, lama masa produktifnya, dan kendala-kendala yang mungkin terjadi.

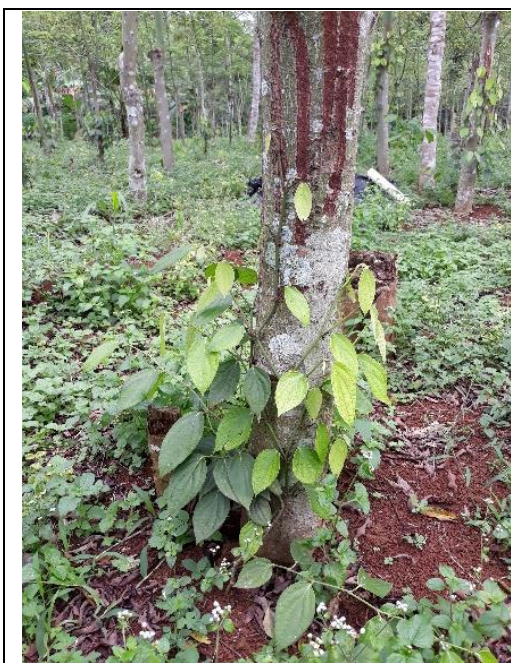

(a)

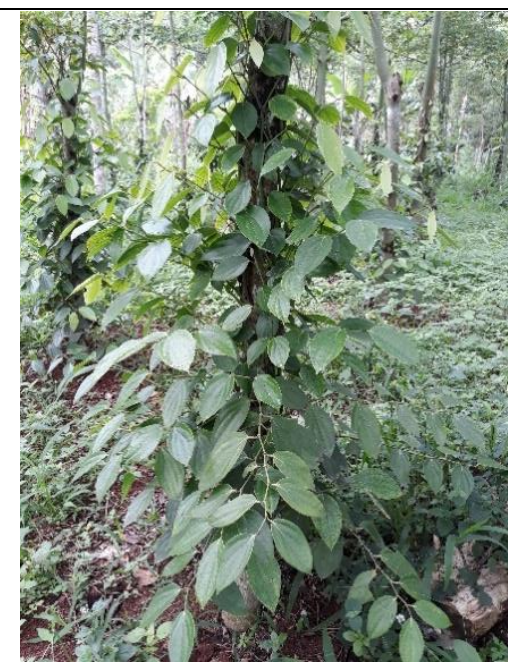

(b)

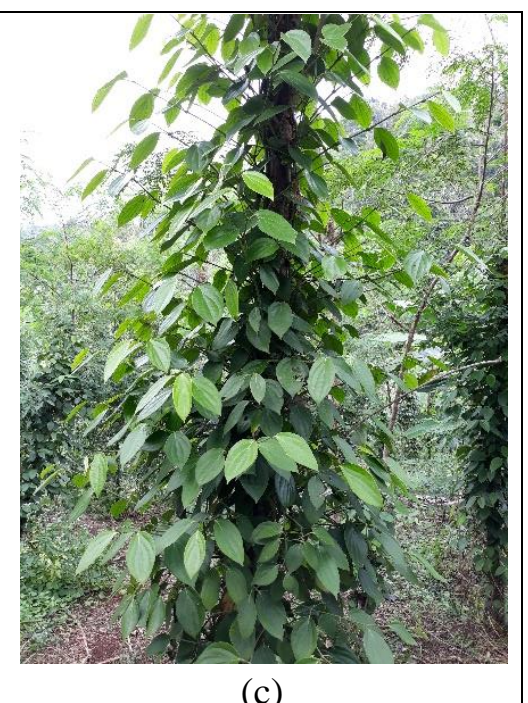

(c)

Gambar 3. Performa pertumbuhan tanaman lada sambung (a) umur 6 bulan, (b) umur 12 bulan, (c) umur 18 bulan

Gambar 3 menyajikan performa tanaman lada sambung pada umur 6-18 bulan. Tanaman lada sambung terlihat tumbuh subur, banyak bercabang buah, siap untuk mendukung pertumbuhan generatif. Agar akar lekat tumbuh kuat melekat pada tajar dari pohon kapuk, maka batang kapuk dikerok dengan golok sehingga membentuk alur panjang. Di Lampung, pohon kapuk merupakan salah satu pilihan pohon rambatan lada selain dadap dan gamal (Evizal 2000).

\section{KESIMPULAN}

Berdasarkan hasil penelitian dapat ditarik kesimpulan sebagai berikut:

(1) Setelah bibit melada ditanam di lahan, maka tanaman melada akan tumbuh dengan daun yang lebih besar akan tetapi warna daun lebih hijau muda dengan indeks kehijauan daun turun dari 0,29 menjadi 0,24 berturut-turut untuk bibit 3 bulan dan melada 2 tahun, membentuk cabang plagiotrop yang berdiameter kecil setiap 1-2 buku cabang ortotrop, dan lambat membentuk cabang ortotrop baru.

(2) Setelah pemangkasan kedua (panen stek kedua) sebanyak 22\% tanaman bercabang ortotrop 2-3 cabang. Hasil stek melada panen kesatu sampai ketiga semakin meningkat 21-25\% dibandingkan hasil sebelumnya. Pada panen ketiga, produksi stek mencapai 5066 stek per luas lahan $400 \mathrm{~m}^{2}$ atau setara 126.650 stek 2 buku per ha lahan yang dipanen setiap 2 bulan.

(3) Hasil pengamatan umur 18 bulan, dibandingkan lada non-sambung, lada 
sambung menunjukkan indeks kehijauan daun yang lebih besar, diameter batang yang lebih besar, diameter cabang plagiotrop yang lebih besar, jumlah cabang ortotrop yang lebih banyak, dan jumlah cabang plagiotrop yang lebih banyak, dan $15,6 \%$ tanaman sudah berbunga.

\section{DAFTAR PUSTAKA}

Alconero, R., F. Albuquerque, N. Almeyda, and A.G. Santiago. 1972. "Phytophthora Foot Rot of Balck Pepper in Brazil and Puerto Rico." Phytopathology 62 (1): 144-48.

An, N.V., N.C. Thanh, N.T. Hai, N.T. Huong, P.T.P Thao, D.T.H. Cam, and P.D.D Nha. 2019. "Evaluate the Effectiveness of Grafted Pepper (Piper Colubrinum 1.) Production in the Southeast and Central Highlands of Vietnam." International Journal of Agriculture \& Environmental Science 6 (6): 78-90. https://doi.org/10.14445/23942568/ijaesv6i6p112.

Chaveerach, A., R. Sudmoon, T. Tanee, and P. Mokkamuli. 2008. "The Species Diversity of the Genus Piper from Thailand." Acta Phytotax. Geobot. 59 (2): 105-63.

Chinnapappa, M., A. Ramar, L. Pugalendhi, P. Muthulakshmi, and P. Vetrivelkalai. 2018. "Screening and Identification of Piper Species as Rootstocks Resistance against the Root Knot Nematode under Glasshouse Condition." Journal of Agriculture and Ecology 6: 77-84. http://saaer.org.in.

Evizal, R. 2000. "Pola Budidaya Lada Sistem Panjatan Hidup Di Propinsi Lampung." Jurnal Agrotropika 5 (2): 14-19.

- 2013. Tanaman Rempah Dan Fitofarmaka. Bandar Lampung: Lembaga Penelitian Universitas Lampung.

Evizal, R., and F.E. Prasmatiwi. 2019. "Agroteknologi Perkebunan Lada Lampung." In Revitalisasi Lada Lampung Sebagai Komoditas Warisan, edited by Hamim Sudarsono and Erwanto, 113-36. Bandar Lampung: Aura Publishing.
Hidayat, N., F. Andriani, F.S.D. Mentari, R.R Manullang, A. Awaludin, and H. Sarie. 2021. "Preparation Planting Material by Grafting of Pepper ( Piper Nigrum L .) With Malada ( Piper Colubrinum L ) for Extensibility in Flooded Land." International Journal of Innovative Science and Research Technology 6 (3): 1290-93.

Jagtap, A.B., R. Sujatha, O.P. Meena, P.A. Nazeem, and S. Pathania. 2016. "MorphoMolecular Characterization of Putative Interspecific Crosses in Black Pepper (Piper Nigrum L. and Piper Colubrinum)." Plant Omics Journal 9 (1): 73-80.

Krishnamurthy, K.S., and K.V. Saji. 2006. "Response of Piper Species to Water Stress." Indian Journal of Horticulture 63 (4): 433-38.

Nguyen, T. Q., T.D.H. Tran, O.D. Thi, N.Q. Ngoc, and B.D. Dang. 2020. "Determination Grafting Techniques and Compatible Grafts between Piper Species - a Case Study in Vietnam." International Journal of Chemical Studies 8 (3): 181720.

https://doi.org/10.22271/chemi.2020.v8.i 3y. 9471 .

Prasmatiwi, F.E., and R. Evizal. 2020. "Keragaan Dan Produktivitas Kebun Lada Tumpangsari Kopi Di Lampung Utara." Jurnal Agrotropika 19 (2): 110-17.

Raja, M. B., S Parthiban, M Anandhan, E Venkadeswaran, K. Pandi, S Suganthi, and M. S. Prakash. 2018. "Rooting and Sprouting Performance of Nodal Cutting of Cultivated and Wild Inter Specific Piper Rootstocks." International Journal of Chemical Studies 6 (2): 20-24.

Ravindran, P N, and A B Remashree. 1998. "Anatomy of Piper Colubrinum Link." Journal of Spices and Aromatic Crops 7 (2): 111-23.

Sinoj, J., T.E. Sheeja, R.S. Bhai, E.J. Suraby, D. Minoot, J. Soji, V.N. Jayakumar, M. Anandaraj, K.C. Bansal, and K.N. Babu. 2014. "Somatic Embryogenesis and Transgenic Development in Black Pepper for Delayed Infection and Decreased 
Spread of Foot Rot Caused by Phytophthora Capsici." Journal of Plantation Crops 42 (1): 20-28.

Sruthi, D., and T. J. Zachariah. 2016. "Phenolic Profiling of Piper Species by Liquid Chromatography-Mass Spectrometry." Journal of Spices and Aromatic Crops 25 (2): 123-32.

Sruthi, D., and T.J. Zachariah. 2017. "In Vitro Antioxidant Activity and Cytotoxicity of Sequential Extracts from Selected Black Pepper (Piper Nigrum L.) Varieties and Piper Species." International Food Research Journal 24 (1): 75-85.

Vanaja, T., V. P. Neema, K. P. Mammootty, and R. Rajeshkumar. 2008. "Development of a Promising Interspecific Hybrid in Black Pepper (Piper Nigrum L.) for Phytophthora Foot Rot Resistance." Euphytica $161 \quad$ (3): 437-45. https://doi.org/10.1007/s10681-0079602-4.

Vijayakumari, K, and J.T. Puthur. 2014. "Drought Stress Responses in Tolerant and Sensitive Varieties of Black Pepper (Piper Nigrum L.)." Journal of Plantation Crops 42 (1): 78-85.

Xue, J., and B. Su. 2017. "Significant Remote Sensing Vegetation Indices: A Review of Developments and Applications." Journal of Sensors 2017 (1353691): 1-17. https://doi.org/10.1155/2017/1353691.

Yadav, S.P., Y. Ibaraki, and S.D. Gupta. 2010. "Estimation of the Chlorophyll Content of Micropropagated Potato Plants Using RGB Based Image Analysis." Plant Cell, Tissue and Organ Culture 100 (2): 18388. https://doi.org/10.1007/s11240-0099635-6.

Yang, S., and P. Chen. 2017. "Cambial Variations of Piper (Piperaceae) in Taiwan." Botanical Studies 58 (17): 1-9. https://doi.org/10.1186/s40529-0170172-z. 